DOI 10.37882/2223-2982.2020.11.37

\title{
ПЕДАГОГИЧЕСКИЕ КАДРЫ КИТАЙСКОЙ ЛЕНИНСКОЙ ШКОЛЫ ${ }^{1}$
}

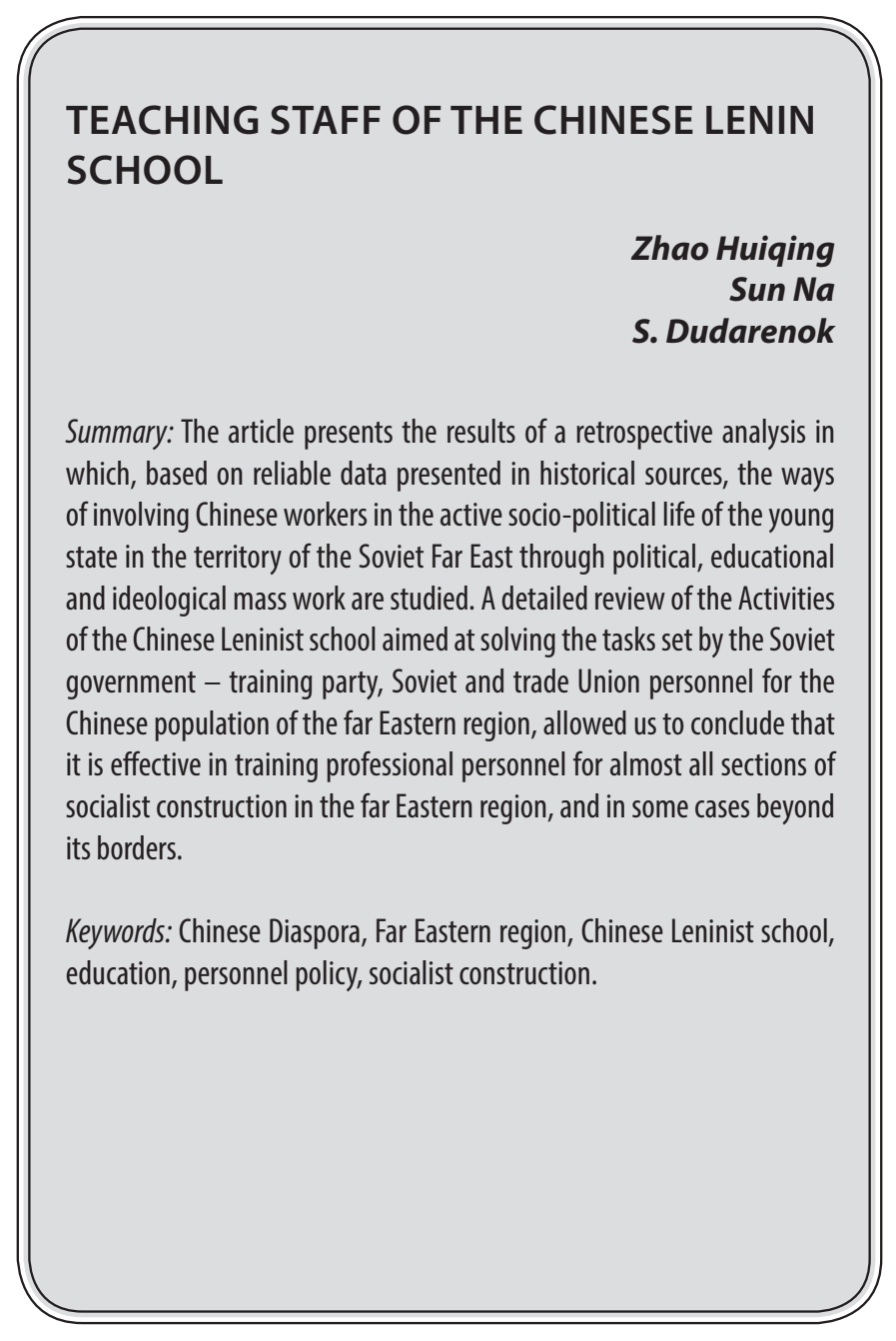

\section{Введение}

Китайская диаспора, проживающая на территории Дальневосточного края (далее - ДВК), всегда находилась под пристальным вниманием Советских властей. Основной целью диаспоры являлась вовлечение китайских трудящихся «<...> в активную общественно-политическую жизнь страны путем проведения политикопросветительской и идеологической массовой работы» [4, с.229-230]. Для её достижения основная деятельность диаспоры была направлена на вовлечение китайских трудящихся в дело социалистического строительства и их приобщение к новым сложившимся на тот период становления молодого государства реалиям на всей территории советского Дальнего Востока путем созда- аспирант, Дальневосточный федеральный университет, г. Владивосток; доцент, Хэйхэский университет, 2. Хэйхэ (КНP) 273004890@q9.com

Сунь $\mathrm{Ha}$

старший преподаватель, Хэйхэский университет,

2. Хэйхэ (KHP)

909389521@q9.com

Дударенок Светлана Михайловна

Д.и.н., профессор, в.н.с., Институт истории, археологии и этнографии народов Дальнего Востока ДВО РАН,

г. Владивосток

dudarenoksv@gmail.com

Аннотация: В статье представлены результаты ретроспективного анализа, в рамках которого на основании достоверных данных, представленных в исторических источниках, изучены пути вовлечения китайских трудящихся в активную общественно-политическую жизнь молодого государства на территории советского Дальнего Востока путем проведения политико-просветительской и идеологической массовой работы. Детальное рассмотрение деятельности Китайской ленинской школы, направленной на решение поставленных Советским правительством задач - подготовку партийных, советских и профсоюзных кадров для китайского населения Дальневосточного края, позволило сделать вывод об её эффективности, заключающейся в подготовки профессиональных кадров практически для всех участков социалистического строительства в Дальневосточном крае, а в ряде случаев - за его пределами.

Ключевые слова: китайская диаспора, Дальневосточный край, Китайская ленинская школа, просвещение, кадровая политика, социалистическое строительство.

ния клубов, открытия Красных уголков и кинотеатров, издания газет на китайском языке, а на предприятиях стенгазет.

Кроме названного диаспорой проводились комплексные мероприятия, направленные на ликвидацию неграмотности и организацию школ по подготовке специалистов по работе с китайским населением. Однако, акцентированное внимание в работе диаспоры уделялось подготовке руководителей политико-просветительской и идеологическо-массовой работы среди китайской диаспоры в совпартшколах, техникумах и институтах. Поддержка деятельности диаспор со стороны региональных государственных структур оказывалась путем принятия соответствующих решений и постанов- 
лений, хотя далеко не все планируемые мероприятия были реализованы в полной мере.

До 1933 г. в систему обучения китайских рабочих входили китайский педагогический техникум во Владивостоке, китайское отделение рабфака, китайское отделение педагогического института, китайское отделение Хабаровского Далькомвуза и Владивостокская китайская Совпартшкола 2-й ступени [4, с.230].

Несколько позже, все названные, в достаточной степени разнотипные учебные заведения в целях концентрации материальной базы и преподавательских сил были объединены в одно учебное заведение. Так, в ходе заседания Секретариата Далькрайкома ВКП(б) 25 января 1933 г. было принято решение о создании Краевой Китайской ленинской школы повышенного типа на основе слияния китайского отделения Далькомвуза и Краевой Китайской Совпартшколы в г. Владивостоке. Официальной датой образования Китайской ленинской школы принято считать 1 марта 1933 г. [2, с. 1, 3-4, 8, 13.], первым директором Китайской ленинской школы был назначен Г.И. Стаканов, а его заместителем по учебной части М.И. Грудинин. Остановимся более подробно на рассмотрении этапов становления Китайской ленинской школы посредством ретроспективного анализа сохранившегося до сегодняшнего дня материала о.

\section{Теоретический анализ по проблеме исследования}

Г.И. Стаканов (Ли-И-Пин, другими именами были ЛиЯо-Куй, Ван-Да-Ли, Ван-Юе-Синь) родился в 1903 г. в деревне Юйцзя уезда Ляочжун провинции Ляонин. В июне 1925 г. Ли-И-Пин вступил в Коммунистический союз молодежи Китая. Ещё проходя обучение на физико-математическом факультете Пекинского университета, стал заниматься коммунистической агитацией, и там же вступил в Коммунистическую партию Китая (далее - КПК). В ноябре 1926 г. Ли-И-Пин был отправлен в Коммунистический университет трудящихся Китая (далее - КУТК), по окончании которого был направлен во г. Владивосток в китайскую совпартшколу преподавателем марксизмаленинизма, после реорганизации которой в Китайскую ленинскую школу возглавлял её до октября 1933 г., впоследствии перейдя на преподавательскую работу в Совпартшколу им. Су-Чжао-Чжэн [5, с.139].

Начиная с сентября 1933 г. новым директором Китайской ленинской школы был назначен И.Н. Гуйский (ЧэньДа-Ган, другое имя Чжан-Си-Чоу), уроженец г. Фучжоу (г. Чунцин провинции (ычуань), получивший образование в Восточном сычуаньском педагогическом институте. В 1924 г. Чэнь-Да-Ган вступил в Коммунистический Союз Молодежи Китая (далее - КСМК), а в 1926 г. - в КПК. Зимой 1927 г. Чэнь-Да-Ган был отправлен в Коммунистический университет трудящихся Востока им. И. В. Сталина (далее - КУТВ), а на следующий год был переведен в Коммунистический университет трудящихся Китая им. Сунь Ятсена (далее - КУТК), по окончанию которого был отправлен в г. Владивосток для работы в Совпартшколу им. Су-Чжао-Чжэн. По возвращению Чэнь-Да-Гана в Китай в августе 1948 г., был назначен заместителем директора Харбинского института иностранных языков, а в ноябре 1949 г. переведен на должность заместителя начальника Бюро по переводу и составлению работ на русском языке ЦК КПК, одновременно исполняя обязанности директора Пекинского института русского языка. Умер ЧэньДа-Ган 5 мая 1989 г. [2, с. Л. 1; 5].

Осенью 1933 г., в связи с необеспеченностью преподавателями, слабой партийной прослойкой китайского отдела Интрпединститута и Интрпедрабфака, в целях организации системы повышения образования так называемого нормального типа для китайских трудящихся и наиболее целесообразного использования имеющихся национальных преподавательских кадров, на бюро Приморского Обкома ВКП(б) и совещании директоров ВУЗов ДВК был поставлен вопрос о слиянии китайских отделений Интрпединститута [2, с. 3-4, 5, 8, 13, 14.] и Интрпедрабфака с Китайской ленинской школой. С этого времени она стала называться «Дальневосточной Китайской ленинской школой повышенного типа» став единственным в Дальневосточном крае и в СССР китайским учебным заведением при Наркомпроссе. Школа рассматривалась в качестве своеобразного политического учебного заведения в рамках образовательного процесса которой осуществлялась подготовка кадров не только для политико-просветительской работы, но и для устройства в органах оборонного значения, в том числе военных и политических (так называемой спецработы) Дальневосточного края [6, с.16].

Постановлением Дальневосточного краевого комитета ВКП(б) от 29 сентября 1933 г. в распоряжение Китайской ленинской школы передавались все студенты и преподаватели китайских отделений Интерпединститута, Интерпедрабфака, а также занимаемое студентами общежитие [2, с. 3-4, 5, 8, 13, 14].

Несмотря на то, что Школа формально находилась в ведении Народного Комиссариата по просвещению и её основной задачей была подготовка национальных кадров для работы с китайцами, проживающими на территории Дальневосточного края, главными инициаторами создания Школы были Центральный Комитет ВКП(б) и Исполнительный Комитет Коммунистического Интернационала, а главной, не афишируемой задачей - подготовка национальных кадров для будущей мировой революции. При благоприятном развитии событий Китай должен был стать социалистическим государством и в перспективе войти в «семью братских народов СССР». В случае победы коммунизма во всекитайском масштабе 
потребовались бы «подготовленные и проверенные национальные кадры, которые можно было бы направить в Китай». Непосредственной подготовкой таких перспективных кадров и должна была заниматься Китайская ленинская школа [1, с.252].

М.И. Грудинин в своем письме к Н.К. Крупской отмечает, что Китайская ленинская школа, выступающая в качестве единственного высшего учебного заведения для китайских трудящихся, играет важную роль в подготовке кадров военных и политических учреждений в Дальневосточном крае [5, с.112].

Благодаря объединению китайских отделений Интерпединститута и Интерпедрабфака была решена задача по обеспечению Школы преподавательскими кадрами - лучшие преподавательские кадры были сконцентрированы в Ленинской школе. В 1933-1934 уч. году 13 преподавателей из 23 являлись членами ВКП(б), 4 - членами ВЛКСМ [2, с.23].

Качество подготовки преподавателей Китайской ленинской школы было достаточно высоким. Большинство китайских преподавателей окончили Коммунистический университет трудящихся Китая им. Сунь Ятсена (далее КУТК), Коммунистический университет трудящихся Востока им. И. В. Сталина (далее - КУТВ) или Коммунистический университет преподавателей общественных наук (далее - КУПОН), имели большой стаж преподавательской деятельности в высших и средних учебных заведениях и хорошо владели русским языком. Так, например, Ян-Хин-Шунь, окончивший КУПОН, преподавал один год (в 1932-1933 уч. год) в Москве в КУТВ, в 1934 г. работал в Ленинской школе и по совместительству в Дальневосточном государственном университете (далее - ДВГУ), где осуществлял преподавательскую деятельность в рамках учебной дисциплины «Диалектический материализм» на русском языке; Я.П. Носов (Дю-Нян-Цзу) преподаватель Ленинской школы неоднократно приглашался на постоянную работу на Востфак ДВГУ, так как мог вести занятия на русском языке; Ф.А. Валецкий, окончивший КУТК в 1929 г., являлся бывшим редактором газеты «Китайский Рабочий». Преподавателями Китайской ленинской школы были: Тин-Шань - доцент, переведенный в Китайскую Ленинскую школу из Хабаровского Комвуза, Г.И. Стаканов и многие др. [2, с.23-24].

Часть преподавателей Китайской ленинской школы имели научные и научно-методические труды: Н.П. Улитин - ученый, сотрудник Дальневосточного филиала Академии наук, В. К. Врубель (И-Тин-Сян) - автор учебников «Экономическая география» и «Анатомия и физиология» на китайском языке, изданных Дальгизом для китайских учебных заведений, Тин-Шань - автор учебников по китайскому языку для школ первой ступени, брошюр на латинском языке, китайских пьес для китайского ТРАМа, К.М. Либов (Лян-Тин-Сян) - автор китайских учебников по естествознанию и математике для Ленинской школы. Значительная часть преподавателей занималась переводами с русского на китайский и наоборот [2, с.23].

Школа имела тесные научные и научно-методические контакты с Ленинградским институтом востоковедения Академии наук СССР. По договоренности с Академией наук на должность заведующего кафедрой языкознания был приглашен филолог-востоковед А.А. Драгунов (1900-1955 гг.) - советский филолог-востоковед, исследователь китайского языка, тибетолог. Занимаясь изучением дунганского языка и диалектов китайского языка, им была открыта неизвестная до того времени группа диалектов Центрального Китая, проведена большая работа по восстановлению фонетической структуры среднекитайского языка XII-XIV вв., исследованы проблемы частей речи в китайском языке и найдены ответы на многие другие вопросы фонологии и грамматики китайского языка.

В течение 1933-1934 гг. А.А. Драгунов работал в ДВК (в Ленинской школе и в группе разработчиков нового алфавита) и в Ленинградском институте востоковедения Академии наук СССР. В Китайской ленинской школе он заведовал кафедрой языкознания, преподавал русский и китайские языки, вел спецсеминары по методике преподавания китайского языка и диалектологии [2, с.24].

В 1934-1935 уч. году в Китайской ленинской школе свою профессиональную деятельность осуществляли 27 преподавателей, педагогическая нагрузка которых представлена в таблице 1.

Из таблицы 1 видно, что как для подготовительного курса, как и для средней и повышенной ступеней в учебном плане Китайской ленинской школы (далее - Школа) значительное внимание уделялось дисциплинам идеологического характера, а также повышению уровня знания китайского и русского языков.

Уровень квалификации преподавателей соответствовал требованиям: из 27 преподавателей 13 (48,1\%) были доцентами, 5 (18,5\%) старшими преподавателями, остальные $9(33,4)$ - ассистентами. Заведующими кафедрами были назначены: Носов (кафедра истории), Либов (кафедра социально-экономических дисциплин) и Шпринцин (языковая кафедра). Методическую комиссию возглавил Маякевич. Указанные часы, отводимые на занятия, были постоянной годовой нагрузкой преподавателя, сюда же включался и отпуск. Бухгалтерия производила соответствующий расчет помесячной зарплаты согласно существующим указаниям НКП. У тех преподавателей, которые не проводили часы по расписанию, удерживали суммы из зарплаты и выплачивали тем, кто 
Состав преподавателей Китайской ленинской школы в 1934/1935 уч. году [6, с.16]

\begin{tabular}{|c|c|c|c|c|c|c|}
\hline \multirow[t]{2}{*}{ Ф.И. преподавателя } & \multirow[t]{2}{*}{ Штат. / нештат. } & \multirow[t]{2}{*}{ Категория } & \multirow[t]{2}{*}{ Преподаваемые предметы } & \multicolumn{3}{|c|}{ Часы } \\
\hline & & & & ПС & $\mathrm{CC}$ & ПК \\
\hline 1 & 2 & 3 & 4 & 5 & 6 & 7 \\
\hline Г.И. Стаканов & шт. & доцент & Ленинизм & - & 320 & - \\
\hline Ф.А. Валецкий & шт. & доцент & Политэкономия & 120 & 440 & - \\
\hline \multirow[t]{2}{*}{ К.М. Либов } & \multirow[t]{2}{*}{ шт. } & \multirow[t]{2}{*}{ доцент } & Экономика, Политология, Экономика Китая & 80 & 500 & - \\
\hline & & & Преподавание организации производства и труда в колхозах & - & 90 & - \\
\hline \multirow[t]{2}{*}{ Ян-Хин-Шунь } & \multirow[t]{2}{*}{ шт. } & \multirow[t]{2}{*}{ доцент } & Диамат & - & 280 & - \\
\hline & & & Партийно-массовая работа в промышленной группе & - & 20 & - \\
\hline Л.К. Маякевич & шт. & ассистент & История Запада и Востока & - & 560 & - \\
\hline \multirow[t]{2}{*}{ Тин-Шань } & \multirow[t]{2}{*}{ шт. } & \multirow[t]{2}{*}{ доцент } & История комитета и кит. революции & 130 & 460 & - \\
\hline & & & Парт. работа. и сост. колхозов & - & 60 & - \\
\hline Син-Тин-Сань & шт. & препод. & Политграмота & - & - & 230 \\
\hline Л.Л. Саликова & шт. & ассистент & История ВКП(б) и политграмота & - & 400 & 460 \\
\hline \multirow[t]{2}{*}{ Милюков } & \multirow[t]{2}{*}{ шт. } & \multirow[t]{2}{*}{ ассистент } & $\begin{array}{c}\text { Переводчик экономической промышленности и организаци- } \\
\text { онной. промышленности }\end{array}$ & $=$ & 180 & - \\
\hline & & & Физ. и экон. география & - & 370 & 345 \\
\hline \multirow[t]{2}{*}{ Я.П. НосОВ } & \multirow[t]{2}{*}{ шт. } & \multirow[t]{2}{*}{ доцент } & Педагогическая дисциплина & 180 & 140 & - \\
\hline & & & История России и СССР & - & 180 & - \\
\hline Воровский & шт. & $\begin{array}{c}\text { преподава- } \\
\text { тель }\end{array}$ & Естествознание & - & 75 & 605 \\
\hline \multirow[t]{3}{*}{ В.К. Врубель } & \multirow[t]{3}{*}{ шт. } & \multirow[t]{3}{*}{ ассистент } & Естествознание & - & 225 & 200 \\
\hline & & & Биология и химия & 230 & 200 & - \\
\hline & & & Общая агроном (препод. или переводчик) & - & 80 & - \\
\hline М.К. Смидович & шт. & доцент & $\begin{array}{c}\text { Литературный китайский язык, методика преподавания } \\
\text { китайского языка }\end{array}$ & 130 & 390 & 205 \\
\hline Борит & шт. & ассистент & Китайский язык & - & 600 & 205 \\
\hline Озмидов & шт. & ассистент & Китайский язык & - & 240 & 615 \\
\hline Е.Г. Разволяева & шт. & ассистент & Русский язык & 240 & 440 & - \\
\hline Л.Д. Позднеева & шт. & ассистент & Русский язык & - & 720 & 200 \\
\hline Морошкина & шт. & ассистент & Русский язык & - & - & 400 \\
\hline М.И. Грудинин & шт. & ассистент & Русский язык & - & 200 & - \\
\hline- & - & - & Пение & - & 90 & - \\
\hline- & - & - & Рисование & - & 130 & - \\
\hline Ли Коист. Павл. & - & - & Физкультура & 50 & 315 & 150 \\
\hline Желнин & шт. & доцент & Военное дело & 70 & 130 & - \\
\hline \multirow[t]{2}{*}{ Ши-Ю } & \multirow[t]{2}{*}{ шт. } & $\begin{array}{c}\text { преподава- } \\
\text { тель }\end{array}$ & Военное дело & - & 170 & - \\
\hline & & переводчик & Военное дело & 70 & 130 & - \\
\hline Топорищев & нешт. & ассистент & Экономика и органическая промышленность & - & 180 & - \\
\hline Тун-Ян-Цзу & шт. & препод. & Арифметика & - & - & 660 \\
\hline Ма-Ши-Цзэ & шт. & препод. & Математика и физика & 100 & 515 & - \\
\hline
\end{tabular}

Примечание: ПС - повышенная ступень, СС - средняя ступень, ПК - подготовительные курсы 
реально преподавал их дисциплины [6, с.16].

В 1935-1936 уч. году в Школе работало 28 преподавателей, 19 из которых были китайцами, 9 - русскими. К середине 1936 г. численность преподавателей сократилось до 24 чел. Среди них китайских преподавателей было 16 чел., русских - 8 чел. Из китайских преподавателей высшее образование имели 12 чел. (обучение проходили в советских комвузах), 2 из них прибыли в Россию в 1916 г., а остальные с 1923 по 1930 гг. 8 чел. из китайских преподавателей являлись членами ВКП(б), 2 чел. - кандидатами в члены ВКП(б), 1 чел. - член ВЛКСМ, 2 чел. - сочувствующих и 3 чел. - беспартийных. Из русских преподавателей 5 чел. закончили или Востфак ДВГУ, Институт Востоковедения им. Нариманова или Ленинградский университет, 4 чел. являлись членами ВКП(б), 2 чел. - членами ВЛКСМ, 1 чел. - сочувствующий и 1 чел. - беспартийный [3, с.11-12].

Отсутствие учебных пособий на китайском языке вынуждало преподавателей самостоятельно переводить их с русского на китайский иероглифический и на латинизированный языки с тем, чтобы обеспечить учащихся всеми необходимыми учебными пособиями и материалами.

Преподавателями Школы были переведены на китайский язык ряд учебников. Среди них: учебник арифметики в 2-х частях Н.С. Попова, алгебры А.П. Кисилева, зоологии, биологии, ботанике, эволюционному учению, физике, геометрии и пр. Из учебников по общественнополитическим дисциплинам были переведены учебник по политэкономии Л. Сегаля, Истории ВКП(б) В.Г. Кнорина, ряд глав из «Развития капитализма в России» В.И. Ленина, «Очерки по истории Китая» и ряд философских произведений В.Н. Ральцевича [3, с.13].

В соответствии с планом издательской деятельности преподавателями Школы постоянно переводились статьи К. Маркса, Ф. Энгельса, В.И. Ленина, И.В. Сталина, статьи из журналов «Большевик» и др. [2, с.22].

\section{Выводы}

Таким образом, уровень профессиональной подготовки преподавательского состава Китайской ленинской школы позволял решать поставленную перед ней задачу - подготовку партийных, советских и профсоюзных кадров для китайского населения ДВК. В рассмотренный исторический период не было ни одного крупного промышленного предприятия, завода, шахты, прииска, новостройки где бы не работали «питомцы Школы» в качестве бригадиров, парторгов, профоргов, культработников, председателей колхозов, инструкторов по национальной работе РИКов и Горсоветов, инструкторов Комитета нового алфавита, преподавателей ликпунктов, школ малограмотных, начальных детских школ - одним словом практически на всех участках социалистического строительства в ДВК, а в ряде случаев - вне его.

ЛИТЕРАТУРА

1. Анча Д.А., Мизь Н.Г. Китайская диаспора во Владивостоке: страницы истории. Изд. 2-е, доп. Владивосток: Дальнаука, 2015. С.252.

2. ГАПК. Ф. П-1190. ОП. 1, Д. 3, Л. 1-5, 8, 14, 22-24.

3. ГАПК. Ф.П-1190. ОП. 1. Д. 7.Л. 4-6; Д. 11. Л. 11, 12.

4. Исаев А.А. Китайская Ленинская школа на Дальнем Востоке СССР в 1930-е гг.: политико-идеологический аспект деятельности // Россия и Китай: история и перспективы сотрудничества. Материалы VII Международной научно-практической конференции (Благовещенск — Хэйхэ, 22 - 23 мая 2017 г.). Вып. 7 / Отв. ред. Д.В. Буяров, Д.В. Кузнецов. Благовещенск: Изд-во БГпУ, 2017. С. 229-230.

5. Нин Яньхун. 宁艳红. 百年华侨史. Байнянь Хуацяо Ши. Столетняя история китайских мигрантов. Гуанчжоу: Издательство Цзинаньского университета, 2019. С.112, 139.

6. РГИА ДВ. Ф.Р-102. 0п. 1. Д. 2.Л. 16.

7. Щуковская Ю.П. Из истории организации политико-просветительского образования среди китайского населения в Приморском крае. 1923-1939 // Вестник архивиста. 2009. № 3. С. 128-143.

( Чжао Хуэйцин (273004890@qq.com), Сунь На (909389521@qq.com), Дударенок Светлана Михайловна (dudarenoksv@gmail.com).

Журнал «Современная наука: актуальные проблемы теории и практики» 